\title{
STUDENTS' PERCEPTION ON THE USE OF AUTHENTIC MATERIALS IN SENIOR HIGH SCHOOL
}

\author{
Eka Firmansyah \\ SMAN I Sindangkerta Jawa Barat \\ Korespondensi: J1. Raya Puncaksari - Sindangkerta \\ E-mail: ekafirmansyah03@gmail.com
}

\begin{abstract}
This study aims to find out the senior high school students' perception on the use of materials (authentic and non-authentic) in the classroom. To select the representative sample, a sampling method was used. This research observes the perceptions of 10 first-grade students of a Senior High School on the use of authentic and non-authentic materials. They were taught using both materials, authentic and non-authentic. After that, to collect the data, they were asked to fill in the questionnaire (Likert Scale) which showed the students' perception toward both materials, authentic and non-authentic. Then, the data were analyzed based on two different categories proposed by Peacock (1997) which covered: (1) overall class interest and enthusiasm and (2) self-reported interest \& enthusiasm. The result of the study indicated that authentic and non-authentic materials had their own benefit. The students indicated that the authentic materials slightly higher than the nonauthentic ones.
\end{abstract}

Keywords: EFL Methodology, english subject, materials (authentic and non-authentic).

\begin{abstract}
Abstrak
Penelitian ini bertujuan untuk menemukan persepsi para siswa terhadap penggunaan materi dalam pelajaran Bahasa Inggris (otentik dan non-otentik). Metode sampel digunakan untuk memilih sampel yang benar-benar mewakili keseluruhan populasi. Penelitian ini berupaya mengobservasi persepsi dari sepuluh siswa/siswi kelas $X$ di sekolah menengah atas terhadap penggunaan materi pelajaran Bahasa Inggris yang berbentuk otentik dan non-otentik. Pada tahap proses pengumpulan data, para siswa/siswi mengisi angket (menggunakan skala Likert) yang menunjukkan persepsi mereka terhadap penggunaan bahan materi pelajaran Bahasa Inggris yang otentik dan non-otentik. Selanjutnya, data yang terkumpul dianalisis berdasarkan dua kategori dari Peacock (1997), yaitu: (1) antusiasme dan minat keseluruhan kelas. (2) antusiasme dan minat diri sendiri. Hasil dari penelitian ini menunjukkan bahwa masing-masing bentuk materi, baik otentik maupun nonotentik memberikan manfaat bagi siswa. Para siswa memberikan persepsi positif lebih tinggi terhadap penggunaan materi otentik dibandingkan dengan non-otentik.
\end{abstract}

Kata-kata kunci: Metodologi pengajaran bahasa Inggris, materi otentik dan non-otentik

\section{INTRODUCTION}

Using authentic material in language teaching has been popular recently. Many teachers experienced that their students felt bored when they were using non-authentic/commercial material such as text book. They cannot get beyond the limitation of a text. The 
benefits of using authentic material may range from highlighting comprehension, presenting real language, providing opportunities to introduce cultural issues, to enhancing motivation, and creating language awareness. However, the use of authentic material in learning context has always been a matter of controversy. In this respect, the present study aims to find out the senior high school students' perception on the use of authentic material in the class.

The first thing we have to consider is the difference definition from both authentic material and nonauthentic/commercial material. Nunan (1999) defines authentic materials as spoken or written language data that has been produced in the course of genuine communication, and not specifically written for purposes of language teaching. We can also refer to Gebhard's (1996) brief description of the term "authentic": Authentic material means anything that is used to communicate. In contrast, (Peacock, 1997) argues that non-authentic material (commercial material) texts that are especially designed for language learning purposes. The language in non-authentic material text is artificial and unvaried, concentrating on something that has to be taught.

In line, Peacock (1997) argues that the purpose of authentic material is for social importance, Newspaper for example, it is made for the sake of information and communication through reading the news. Teacher can take material from newspaper, but of course without the teaching-learning purpose, still, he also describes that non-authentic material (commercial material) texts that are especially designed for language learning purposes. The language in nonauthentic material text is artificial and unvaried, concentrating on something that has to be taught.
According to Berardo (2006), authentic material has a positive value that make students highly motivated. The main reason for using authentic material in the classroom is to make students not only learn in the 'safe' area and controlled language learning environment, but also to encounter the language used in the real world. Meanwhile, the language in nonauthentic text is artificial and unvaried, concentrating on something that has to be taught and often containing a series of "false-text indicators" that include: perfectly formed sentences (all the time); a question using a grammatical structure, gets a full answer, repetition of structures; very often does not "read" well. Those indicators show that the nonauthentic material will not make students know how English is really used in a real-world context and apply their knowledge in the real-world English. Non-authentic materials are actually useful for teaching structures but are not very good for improving reading skills.

His study shows that by using authentic material, students will be able to apply their knowledge that they get in the class into the real condition outside the class. He also finds that in developing reading comprehension, one of the most useful authentic material resources is the internet, with large amounts of varied material being easily accessible.

In the other side, Peacock's study (1997) on the effect of material authenticity toward EFL learners used three different categories (on-task behavior, overall class interest \& enthusiasm, and self-reported interest \& enthusiasm). His research project aims to investigate whether authentic materials increase the classroom motivation of learners. A definition of motivation relevant to teachers was adopted-learner interest, persistence, attention, action, and enjoyment. Two beginner-level EFL 
classes participated, and both used authentic and artificial materials alternately. Results from two observation sheets and a self-report questionnaire indicate that while on-task behaviour and observed motivation increased significantly when authentic materials were used, self-reported motivation only increased over the last 12 of the 20 days of the study. However, learners also reported authentic materials to be significantly less interesting than artificial materials.

Other researchers such as McNeill (1994) and Miller (2003) claimed that all levels of student even lower levels are able to use authentic material. While Kilickaya (2004) and Kim (2000) believed that authentic material can only be applied on intermediate and advance level students.

However, the issue of authentic material is not only about which one is better, but also about how it is best applied to the teaching and learning process. In many school contexts, learners commonly are not involved in choosing what materials to be used, instead it is the teachers themselves who give and determine the kind of material for them. For some cases, students' perception to the material is usually ignored, although the ones who need the material are the students. Based on the condition above, this study is going to investigate students' perception on the use of authentic material in the class. It's hoped that this study can help the English teachers in senior high school level to understand the learners' perception on the use of authentic material in learning English and able to deliver material, either authentic or commercial depend on students' needs.

The present study was conducted in one senior high school in West
Bandung Regency. The research question is: What is students' perception on the use of authentic material in the level of Senior High School? It's hoped after the research question was answered, teachers will be able to identify the most suitable type of material to be delivered for students.

\section{METHOD}

In accordance with the field of the investigation, this study draws on a survey conducted with 10 first-grades a Senior High School student (sample). To select the representative sample, a sampling method was used. The writer used a quota sampling method in this study. As Arikunto (1998: 130) states that "quota sampling method is based on a particular proportion of a population." Then, it employs questionnaire (they are set to 4 Likert Scales: Strongly Disagree, Disagree, Agree, and Strongly Agree). At the end, it will answer the research question: What is students' perception on the use of authentic material in the level of Senior High School?

\section{RESULTS AND DISCUSSION}

\section{Data Presentation to Answer Research Question}

To answer the research question "What is students' perception on the use of authentic material in the level of Senior High School? the result of the research showed that the samples had positive attitudes toward both authentic and non-authentic materials. In the first meeting $(80,82 \%)$ of the samples had positive attitudes toward authentic material, while (80\%) of them showed the same attitudes toward non-authentic material. In the second meeting $(91,68 \%)$ of the students gave positive answers to the authentic material and $(83,32 \%)$ of 
them to non-authentic material. In contrast, in the third meeting $(79,99 \%)$ of the students showed their positive attitude to the authentic material, while $(92,51 \%)$ of had the positive answers to the non-authentic material. Finally, in the last meeting $(95,01 \%)$ of the students had positive answers to the authentic material and $(79,15 \%)$ of them showed positive answers as well to the non-authentic ones.

Based on the students' perceptions in all questionnaires, it was found that the students favored authentic material more than the non-authentic ones in three different meetings, i.e. meeting 1, 2 and 4. On the other hand, in the meeting 3 the students' positive perception in non-authentic material was higher than the authentic one. However, overall I found that on average positive attitudes toward authentic materials $(86,87 \%)$ did not significantly differ from the non-authentic ones $(83,74 \%)$. In other words, the result of the study showed that the students' attitude toward both materials, authentic and non-authentic, was almost the same equal.

Table 1 . The percentage of the total response on both materials (authentic and non-authentic)

\begin{tabular}{lcccc}
\hline Observation & \multicolumn{2}{c}{ Authentic Material } & \multicolumn{2}{c}{ Non-Authentic Material } \\
\cline { 2 - 5 } day & $\begin{array}{c}\text { Strongly } \\
\text { disagree and } \\
\text { disagree }\end{array}$ & $\begin{array}{c}\text { Strongly agree } \\
\text { and agree }\end{array}$ & $\begin{array}{c}\text { Strongly } \\
\text { disagree and } \\
\text { disagree }\end{array}$ & $\begin{array}{c}\text { Strongly agree } \\
\text { and agree }\end{array}$ \\
\hline Meeting 1 & $19,18 \%$ & $80,82 \%$ & $20 \%$ & $80 \%$ \\
\hline Meeting 2 & $8,32 \%$ & $91,68 \%$ & $16,68 \%$ & $83,32 \%$ \\
\hline Meeting 3 & $20,01 \%$ & $79,99 \%$ & $7,49 \%$ & $92,51 \%$ \\
\hline Meeting 4 & $4,99 \%$ & $95,01 \%$ & $20,85 \%$ & $79,15 \%$ \\
\hline Average & $13,12 \%$ & $86,87 \%$ & $16,25 \%$ & $83,74 \%$ \\
\hline
\end{tabular}

\section{Interpretation to the Findings}

In regards to overall class interest $\&$ enthusiasm category, I found that the students gave various perceptions to both authentic and non-authentic materials. Related to statement number 1 , from all questionnaires, the students admitted that they were more actively involved in the learning when they were being taught using authentic materials (82,5\%) compared to non-authentic ones (80\%). In other words, we could say that the students' attitude manifested by the level of activity was higher when they were being taught using authentic materials.

Table 2. The percentage of the total response on each statement (authentic and non-authentic)

\begin{tabular}{lcccc}
\hline \multirow{2}{*}{$\begin{array}{c}\text { Questionnaire } \\
\text { Statements }\end{array}$} & \multicolumn{2}{c}{ Authentic Material } & \multicolumn{2}{c}{ Non-Authentic Material } \\
\cline { 2 - 5 } & $\begin{array}{c}\text { Strongly } \\
\text { disagree and } \\
\text { disagree }\end{array}$ & $\begin{array}{c}\text { Strongly agree } \\
\text { and agree }\end{array}$ & $\begin{array}{c}\text { Strongly } \\
\text { disagree and } \\
\text { disagree }\end{array}$ & $\begin{array}{c}\text { Strongly agree } \\
\text { and agree }\end{array}$ \\
\hline Statement 1 & $17,5 \%$ & $82,5 \%$ & $20 \%$ & $80 \%$ \\
\hline Statement 2 & $12,5 \%$ & $87,5 \%$ & $15 \%$ & $85 \%$ \\
\hline Statement 3 & $5 \%$ & $95 \%$ & $12,5 \%$ & $87,5 \%$ \\
\hline Statement 4 & $15 \%$ & $85 \%$ & $17,5 \%$ & $82,5 \%$ \\
\hline Statement 5 & $12,5 \%$ & $87,5 \%$ & $17,5 \%$ & $82,5 \%$ \\
\hline
\end{tabular}




\begin{tabular}{lcccc}
\hline Statement 6 & $10 \%$ & $90 \%$ & $15 \%$ & $85 \%$ \\
\hline Statement 7 & $7,5 \%$ & $92,5 \%$ & $30 \%$ & $70 \%$ \\
\hline Statement 8 & $12,5 \%$ & $87,5 \%$ & $20 \%$ & $80 \%$ \\
\hline Statement 9 & $12,5 \%$ & $87,5 \%$ & $22,5 \%$ & $77,5 \%$ \\
\hline Statement 10 & $10 \%$ & $90 \%$ & $12,5 \%$ & $87,5 \%$ \\
\hline Statement 11 & $10 \%$ & $90 \%$ & $15 \%$ & $85 \%$ \\
\hline Statement 12 & $20 \%$ & $80 \%$ & $22,5 \%$ & $77,5 \%$ \\
\hline Average & $10,04 \%$ & $87,92 \%$ & $16,45 \%$ & 81,66 \\
\end{tabular}

Similarly, on the statement number 2, when being asked about their level of concentration, I found that students could concentrate more when they were learning English using authentic materials $(87,5 \%)$ than the nonauthentic ones (85\%). It might indicate that the students' activity and concentration had a sort of relation. When the students could concentrate in certain lesson, they might be more active in following that lesson.

From these two statements, related to students' "activity" and "concentration" level, the students gave higher positive attitude to authentic materials (both on statement number 1 and 2).

On the other hand, regarding to the level of enjoyment (statement number 3 ) in using authentic and non-authentic materials, i found that the students slight enjoyed learning English using authentic materials $(95 \%)$ than non-authentic ones $(87,5 \%)$. The finding was quite predictable because earlier stated that the students were actively involved when being taught using authentic materials. Also, they enjoyed learning English more using authentic ones. It could be assumed that authentic materials made the students much more relax and gave them more enjoyment than in non-authentic materials when learning English. The finding might also suggest that there was a close relationship between students' active learning and the level of enjoyment toward the materials, though further analysis needed to be carried out.

It was also found that on average, regarding to statement number 4 , the students paid better attention to the authentic materials (85\%) compared to the non-authentic materials $(82,5 \%)$. It means that the authentic materials were more interesting for the students, it attracted the students' attention more than the nonauthentic ones. In line with this fact, Kienbaum, et al (1986) stated that a material had to relate to or be able to awaken the students' interest. For additional evidence, on the first day teaching, the teacher taught about "describing people". For the authentic material, the material was taken from some peoples' description with their colorful pictures which are printed from internet (David Beckham and Ashanti pictures). At first, when the students saw the pictures, the students really liked them, as we know that David Beckham was a famous foot ball player from Manchester United in 1993-2003, and Ashanti is one of the best Indonesian female singers. They started to describe physical appearance from David Beckham and Ashanti enthusiastically. Meanwhile, when the students were given a text entitled "Vote for Susan Daron" taken from "Look Ahead 1" text book for the non-authentic material, the students didn't really like it. When some 
questions about that description text were asked, only two until three students raised their hands. They felt that Susan Daron was not familiar to them. From that point, it could be inferred that the authentic materials had successfully attracted more attention from the students because the level of difficulty was lower and the topic was more familiar than the non-authentic ones.

Statement number 5 also had a strong relation with the level of difficulty. It was showed that the students preferred to work harder when they were given the authentic materials $(87,5 \%)$ than when they were given the non-authentic ones $(82,5 \%)$. When we talked about the students' hard work in following the lesson, we could review again Peacock's theory (1997) of overall class interest \& enthusiasm which discussed the students' attitude toward materials (authentic and non-authentic) in use as manifested by levels of learner interest, enthusiasm, activity, persistence with the learning task, concentration and enjoyment during class. Here, related to the students' hard work, I focused on the term "persistence with the learning task". This case might occur because the students thought that in the authentic materials, they had higher possibility to understand the materials and complete the task than the non-authentic ones.

Furthermore, the result of questionnaire number 6 showed that (90\%) students on average felt more enthusiastic when they were being taught using authentic materials compared to when being taught using non-authentic materials (85\%). In line with this finding, Berardo (2006) argued that the students' lack of enthusiasm could be caused by the language in non-authentic text which is artificial and unvaried, concentrating on something that has to be taught and often containing a series of "false-text indicators" that include: perfectly formed sentences (all the time); a question using a grammatical structure, gets a full answer, repetition of structures; very often does not "read" well. From those evidences, it could be inferred that authentic materials could make the students feel more enthusiastic than when they were being taught with nonauthentic materials.

The similar thing occurred in the statement number 7 , that most of the students stated that the authentic materials $(92,5 \%)$ were more challenging or motivating them in learning English than the non-authentic ones $(70 \%)$. To emphasize this fact, take a look at Berardo's argument (2006) which stated that authentic materials have a positive value that makes students highly motivated.

Moreover, when being asked about the appropriateness of the materials to the students' need (statement number 8), the students answered that the authentic materials were slightly more appropriate $(87,5 \%)$ than the nonauthentic ones (80\%). Overall, they feel that both materials were appropriate for them, it was proven by the number of the students' perception on both materials were more than $95 \%$.

From eight statements which were categorized in the first category, overall class interest \& enthusiasm, it was found that in average students' positive attitude to the authentic materials $(88,43 \%)$ were higher than their positive attitude to the nonauthentic materials $(81,56 \%)$. From those 8 statements, almost all statements (1-8) in which students gave higher positive attitude to the authentic materials than to the non-authentic ones. I could say in other words that in regards to the overall class interest \& enthusiasm, the students showed higher positive attitude toward authentic materials in use as manifested by levels of learner interest, enthusiasm, 
persistence with the learning task, concentration, and enjoyment during class than to the non-authentic ones.

In regard to self-reported interest $\&$ enthusiasm, on average, the students favored authentic materials $(86,87 \%)$ more than non-authentic ones $(81,87 \%)$. Although students gave high positive attitude toward both authentic and nonauthentic materials, the students' positive attitude was higher on the authentic ones. We could see in the statement number 9 "The materials are meaningful for my learning process". It was shown that the students valued the authentic materials more meaningful for their learning $(87,5 \%)$ than the non-authentic ones $(77,5 \%)$. It might suggest that the students' experience when being taught using authentic materials would enrich their English related to the real-world application. The other evidence was when the teacher asked the students which material that was more meaningful to them, they answered that both materials were meaningful and important for them, but the authentic one could give them better simulation of communication in the real-world because the found many real things in the authentic materials. From that point, in this case, it could be inferred that the students valued the authentic materials more meaningful than the non-authentic ones because the authentic material was important and meaningful for them to apply in the real-world.

In the statement number 10 , students felt that the authentic materials were more interesting $(90 \%)$ than the non-authentic ones $(87,5 \%)$. We absolutely think that the term interesting/exciting always related to enthusiasm (statement number 6) since it has synonymous meaning when we looked up in an English dictionary.
However, statement number 10 was on different category with statement number 6. Statement number 10 was included in the self-reported interest \& enthusiasm which valued the materials in use, while statement number 6 was included in the overall class interest \& enthusiasm which was used to know overall students' attitude toward the authentic and nonauthentic materials.

In regards to statement number 11, the students valued the authentic materials as more satisfying (90\%) than the non-authentic ones (85\%). It might indicate that the students got what they needed in the authentic material. They were more relieved when being taught using authentic materials. Finally, in statement number 12 , the students valued the authentic materials as more varied $(80 \%)$ than the non-authentic ones $(77,5 \%)$. It's because of the authentic materials had many sources from our surrounding such as internet, newspaper, television, radio, etc. So, the students got more variation in their materials. For a second time, from overall questionnaires the authentic materials had higher students' positive attitude than the nonauthentic ones.

\section{CONCLUSION}

These results of the study indicated that authentic and nonauthentic materials had their own benefit. The kind of material, whether it was authentic or non-authentic, might not really determine the students' attitude, but the way it was delivered. The other thing was the level of difficulty which could affect the students' perception toward both materials, authentic and nonauthentic. Also, the familiarity to the topic was needed to be considered since the evidence showed that it affected the students' attitude toward the materials. In 
the future, English teacher in senior high school was hoped to understand the learners' perception toward the materials (authentic and non-authentic) in learning English and able to deliver both materials, in accordance with the students' needs.

\section{ACKNOWLEDGEMENTS}

I would like to express my sincere gratitude to: (1) Headmaster of SMAN I Sindangkerta, West Bandung Regency, Mr. Setia Pahlawan, M.Pd, who has given me permission to conduct this study, and; (2) Mrs. Lia Siti Romlah, S.Pd, who has allowed me to conduct this research in her class.

\section{REFERENCES}

Arikunto, S. (1998). Prosedur penelitian: suatu pendekatan praktek. Jakarta: Rineka Cipta.

Berardo, S.A. (2006). "The use of authentic materials in the teaching of reading". The Reading Matrix, Vol. 6 (2), pp. 60-69.

Gebhard, J.G. (1996). Teaching english as a foreign language: a teacher Self-Development and methodology guide. Ann Arbor: The University of Michigan Press.

Kienbaum, B. E. Russel. J.A., \& Welty. S. (1986). "Communicative competencein foreign language learning with authentic materials". Final Project Report. Purdue University, Calumet, Indiana.

Kilickaya, F. (2004). "Authentic materials and cultural content in EFL classroom". TESL Journal, Vol. 10 (7). Retrieved October 26, 2013, from http://iteslj.org/Techniques/Kilicka ya-AuthenticMaterial.html.

Kim, D. (2000). "A qualitative approach to the authenticity in the foreign languageclassroom: a study of university students learning English in Korea". Texas papers in Foreign Language Education, vol. 5 (1). 189-205.

McNeill, A. (1994). "What makes authentic materials different? The case of English language materials for educational television". Papers, Annual International Language in Education Conference, Hong Kong.

Miller, L. (2003). "Developing listening skills with authentic materials". ESL Magazine, Vol. 6(1), pp. 1619.

Nunan, D. (1999). Second Language Teaching and Learning. Boston:Heinle and Heinle Publishers.

Peacock, M. (1997). "The effect of authentic materials on the motivation". EFL Learners in English Language Teaching Journal. Vol.51(2). pp.144-156 